\title{
The Impacts of Publicly and Privately-Owned Banks on Economic Growth in Turkey: A Comparative Analysis
}

Hatice Elanur KAPLAN ${ }^{a, b}$

\begin{abstract}
Certain transfer mechanisms can be expressed with the help of very different theories about how financial development influences economic growth. The ongoing debates on how the banking system contributes to the economy are tried to be explained by those transmission mechanisms. Among these mechanisms, there are bank deposits and credits related to savings and investment indicators, which are essential to the banking system. In this study, the impact of the banking system on the gross domestic product (GDP) is tried to be examined. However, unlike other similar studies, the development of the banking system is taken into consideration on the basis of total assets, which offers a broader perspective on the total of bank deposits and/or credits. Accordingly, the study aims to explicate the possible association between total assets of the publicly-owned commercial banks as well as the privately-owned banks operating in Turkey and the GDP. The analyses performed on the basis of the quarterly data cover the period between the first quarter of 2010 and the third quarter of 2019. The results obtained from the cointegration test and the FMOLS, DOLS, and CCR cointegration regression analyses reveal that both publicly-owned deposit banks and privately-owned deposit banks are related to the GDP in the long-run. Although it is determined that the total assets within both bank groups has a positive impact on the GDP in the long-run, it is found that publicly-owned deposit banks have a greater impact on the GDP in comparison to privately-owned banks.
\end{abstract}

\section{The Impacts of Publicly and Privately-Owned Banks on Economic Growth in Turkey: A Comparative Analysis}

\section{Özet}

Bazı transfer mekanizmaları, ekonomik büyümenin finansal kalkınmadan ne şekilde etkilendiği hususunda çok değişik teorilerin yardımıyla tanımlanabilir. Bankacılık sisteminin ekonomiye hangi yönlerden katkılar sağladığı ile ilgili sürüp giden tartışmalara bu aktarım mekanizmaları kullanılarak açıklama getirilmeye çalışılmaktadır. Söz konusu mekanizmalar içinde, bankacılık sistemi açısından vazgeçilemez konumdaki yatırım ve tasarruf göstergeleri arasında ilgili banka mevduatları ve kredileri mevcuttur. Bu çalışmada bankacılık sisteminin gayri safi yurtiçi hasıla (GSYİH) üzerindeki etkisi incelenmeye çalışılmıştır. Ancak, diğer benzer çalışmalardan farklı olarak, banka mevduatlarının ve/veya kredilerin toplamı hakkında daha geniş bir perspektif sunan toplam aktifler temelinde bankacılık sisteminin gelişimi dikkate alınmaktadır. Bu doğrultuda çalışma, kamuya ait ticari bankalarla birlikte Türkiye'de faaliyet gösteren özel sermayeli bankaların toplam aktifleri ile GSYIHH arasındaki olası ilişkiyi açıklamayı amaçlamaktadır. Üç aylık verilere dayanarak gerçekleştirilen analizler, 2010'un ilk çeyreği ile 2019'un üçüncü çeyreği arasındaki dönemi kapsamaktadır. Eşbütünleşme testi ve FMOLS, DOLS ve CCR eşbütünleşme regresyon analizlerinden elde edilen sonuçlar, hem kamuya ait mevduat bankaları ve özel sermayeli mevduat bankaları aktif toplamlarının uzun dönemde GSYİH ile ilişkili olduğunu ortaya koymuştur. Her iki banka grubundaki varlıkların toplamının uzun vadede GSYİH üzerinde olumlu bir etkiye sahip olduğu tespit edilse de, kamu sermayeli mevduat bankalarının özel sermayeli bankalara kıyasla GSYİH üzerinde daha fazla etkiye sahip olduğu da tespit edilmiştir.
Keywords

Economic growth

Publicly- and privately-owned

banks

Total Assets

Turkey

About Article

Received: 03.07.2020

Accepted: 10.05.2021

Doi: 10.18026/cbayarsos.763909

\begin{tabular}{r} 
Anahtar Kelimeler \\
Ekonomik büyüme \\
Kamu ve Özel Sektör Bankaları \\
Toplam Aktifler \\
Türkiye \\
Makale Hakkında \\
\hline Geliş Tarihi: 03.07.2020 \\
Kabul Tarihi: 10.05.2021 \\
Doi: $10.18026 /$ cbayarsos.763909
\end{tabular}

Doi: 10.18026/cbayarsos.763909

\footnotetext{
a İletişim Yazarı: haticeelanurkaplan@ohu.edu.tr

b Dr. Öğretim Üyesi, Niğde Ömer Halisdemir Üniversitesi, Sosyal Bilimler Meslek Yüksekokulu, Finans Bankacılık ve Sigortacılık, ORCID 00000002-4722-3434
} 


\section{Introduction}

As in many countries, the banking sector is also a crucial and main component of the financial system for the functioning of the economy in Turkey. Although the effectively operating banking sector and financial system affect economic growth positively, the loss of the robust structure of the banking sector may cause the financial system and the country's economy to encounter plenty of problems in the event of a crisis. Therefore, it is essential for the banking sector to maintain its stable structure and to perform accordingly in order to have a profound financial system and a developing economy. The tremendous influence of the banking sector on the economy has made the research studies conducted in this area the center of attention.

Banks, as the most crucial components of the financial sector, are referred to as financial intermediaries that lend money to consumers or investors by borrowing from savers. According to their capital structures, banks are categorized as Publicly-owned, Privatelyowned, and Foreign Banks. Commercial banks, which accept deposits and extend them to those in need as credit, are the most important and most prominent component of the banking sector worldwide (Topak and Talu, 2016: 37).

The economic system consists of two main parts, namely, the real and financial sectors. Investment and production activities are carried out in the real sector. On the other hand, the financial sector performs the function of funding activities in the real sector. The funds from which savings stem in the country are organized by the financial sector in various ways and transferred to the real sector. As an outcome of this fund transfer process provided by the financial sector, the savings turn into investments in the real sector, increasing the capital stock or production capacity in the country. In this sense, it is very crucial for the financial system to develop effectively in order for the financial sector to function effectively by fulfilling such a flow of funds. The financial sector maintains this important function within the framework of the Capital Market and the Money Market. Each market has its own financial instruments and methods. Private sector units are directly financed by means of debt (bonds and bills) and stocks in the Capital Market (Aklan and Nargeleçekenler, 2008).

In the money market, banks convert the deposit accounts created by savers into credits, and they indirectly finance the private sector units. Thus, investment credits offered by banks in the money market constitute an indirect resource of finance for companies. In some countries, the demand for and supply of funds are conducted mostly through the capital market. The demand for and supply of funds in Turkey usually occurs through the banks within the money market. Banks mainly maintain the flow of funds between the financial and the real sectors in Turkey by courtesy of both bank deposits they collect and bank credits they extend. Thus, the increase in bank credits is also the main source of the vivaciousness of economic activities in the real sector. In other words, the wider the credit opportunities provided by banks, the greater the liveliness in the economy. Nevertheless, some economists argue that the causal association between bank credits and economic growth runs from economic growth toward bank credits. Accordingly, the increase in national income increases the total savings and, in turn, causes the deposits originating from bank credits to rise. Thus, there are two distinct approaches to the direction of the causal association between the expansion in the bank credit volume and the economic growth rate. The first approach determines that bank credits result in economic growth, while the second approach claims that economic growth leads to an expansion in bank credits. Accordingly, economists support different views on the effectiveness of policies targeting economic growth by expanding the bank credit volume. 
Therefore, debates on the quality of the association among the variables also lead to the emergence of different views on the effectiveness of growth policies (Sevim, 2016).

As well-known, the basic macroeconomic indicators in an economy consist of national income growth, the balance of payments, price stability, and fair income distribution. In particular, fluctuations in the GDP growth, as well as high savings deficits in countries such as Turkey, tend to manifest themselves as the most basic and persistent macroeconomic problems. Therefore, it is apparent that a stable economic growth rate and a sustainable balance of payments are crucial, both in terms of macroeconomic and financial stability. At this point, the importance of the credit growth in an economy and the course of consumer credits that trigger demand for consumption are discussed extensively by the studies of financial economy literature (Aslan and Korap, 2006).

It is utterly accepted in the literature that excessive credit growth and structural disparities in the balance of payments can account for instability. In general, the question of how financial development influences economic growth is responded to by certain transmission mechanisms that can be explained by various distinct theories. Among these, there are savings and investments related to banks. In many studies conducted on the data of deposits and credits, financial development has been expressed in a very limited portion of bank assets. This study, unlike other similar studies, tries to examine whether or not the development of the banking system in accordance with asset size affects economic growth. In this context, direct and indirect impacts can be mentioned. Upon considering the factors such as savings and credit volume as direct effects, the broadest point of view would be the asset size consisting of all the bank's assets. Since the most inclusive variable to be selected is the asset size, the analyses are performed on the basis of the impacts of the asset size of different bank groups on economic growth. In this context, the objective of this study is to determine the impact of different bank groups' asset size on economic growth.

This study aims to examine the association between the asset sizes of publicly- and privatelyowned banks operating in Turkey and economic growth. Accordingly, the association between the asset sizes of publicly- and privately-owned banks currently operating in Turkey and economic growth is analyzed utilizing the quarterly data obtained over the period from 2010:Q1 to 2019:Q3. Thus, in the introduction section of the study, the conceptual framework for the association between banking-centered financial development and economic growth is explicated. In the second section, previously conducted studies in the related literature are reviewed. In the third section, the dataset and analysis method of the study are introduced, and the empirical findings are reported in the fourth section. Consequently, in the last section of the study, some policy implications for Turkey's economy are made in line with the obtained results of the study.

\section{Literature Review}

\section{Theoretical Framework}

The functions of the financial system have a crucial position in the development of the economic system. Accordingly, discussions on the association between economic growth and financial development have a prominent domain in the literature. By arguing that financial development results in economic growth, economists consider various indicators such as bank deposits, and credit volume as signs of financial development and investigate their impacts on economic growth. In this framework, research studies investigating the association between 
economic growth and bank credits cover an important portion of the literature that concentrates on the association between financial development and economic growth

Bank credits are mostly-utilized sources of funding that affect the economic activities of both consumers and manufacturers. Consumers can continue their consumption activities consistently with the consumer credits extended by banks. In this case, it would increase the profit expectations of entrepreneurs by keeping the total demand constantly vivid in the market. As a result, the investment and production level would be easily boosted in such an environment. However, banks also affect the economic growth positively by courtesy of production with the commercial credits they provide to entrepreneurs. Besides, banks also offer investment credits to entrepreneurs fort hem to venture into new investments. Thus, these credits lead to the development of the capital stock or production capacity in the country. Briefly, banks attain the capacity to accelerate growth in both the short- and long-run by creating vitality in the economy through the consumption and investment credits they provide (Timsina, 2014: 3).

\section{Empirical Literature}

Many studies in the literature detected positive effects of bank credits on economic growth. The vast majority of these studies in the literature investigated the relationship between economic growth and the size of the financial system. There are relatively few studies conducted on bank credit - economic growth nexus, whereas almost no econometric study that investigates the presence of any association between bank deposit and credit volume is conducted. The conversion of bank deposits into credits can be greatly affected by cyclical fluctuations in the country. Interest rates, the expectations of the players in the economic system regarding the country's stability, the government's need for borrowing influence the amount of funds available to those who demand credit. Nonetheless, while the effects of bank deposit and credit volume on economic growth have been intensely examined in the pertinent literature, it is observed that the asset size of the banks has not been analyzed in a natural manner within the knowledge of the researchers. In this context, the studies in which financial development is handled in terms of bank deposits or credits are summarized below.

As one of the pioneering studies investigating the association between use of credit and economic growth in Turkey, Güven (2002) utilized econometric methods such as the Granger causality, variance decomposition, and regression analysis, using the real percent change in the quarterly data of bank credits variable and the percentage change in real GNP variable obtained over the period of 1988-2001. In the study, the Granger causality association was not detected. Nonetheless, variance decomposition and regression results revealed an affirmative association between economic growth and bank credits.

Calderón and Liu (2003) analyzed the impact of bank credit volume (financial development) on economic growth with a sample of 109 developed and developing countries over the period between 1960 - 1994. Panel data analysis indicated the existence of a mutual association between the growth in bank credit volume and economic growth in all countries. This correlation between the variables was intensely experienced in developed countries in which the financial deepening was higher.

Beck and Levine (2004) analyzed the impact of bank credit volume on economic growth in forty countries throughout the period between 1976 - 1998. In the panel data analysis developed using the Generalized Method of Moment (GMM), it was observed that the 
financial developments positively affected the economy especially due to the growth of bank credit volume.

Aslan and Küçükaksoy (2006) analyzed the association between financial development represented by bank credit volume and economic growth throughout the 1970-2004 period in Turkey. Granger causality test results indicated a unilateral association from developments in the bank credit volume toward economic growth in Turkey.

Özcan (2007) analyzed the association between private sector credits and economic growth for 78 countries over the period between 1960 and 2005. Empirical findings revealed the presence of a causal association from economic growth toward credits.

Öztürkler and Çermikli (2007) examined the association between bank credits and economic growth utilizing the VAR model and Granger causality test over the period between 1990 2006. The results of the study revealed a bilateral causality between bank credits and production levels. Accordingly, a mutual causality between bank credits and production level existed in Turkey.

Chakraborty (2008) explicated the impact of financial development indicators on economic growth over the period between 1996 and 2005 in India. The results of cointegration and causality tests carried out within this framework indicated that there was a mutual interaction between economic growth and the development in bank credits. Especially as the bank credit volume increased, the mutual association with economic growth became stronger.

Dişbudak (2010), examined the association between economic growth and bank credits in Turkey between 1961 and 2008. The ARDL Bounds Test results revealed that bank credits positively affected economic growth. It was asserted that the practices to be introduced for the efficient functioning of the credit market would have also contributed to the increase in economic activities, and thus economic growth.

Ceylan and Durkaya (2010) confirmed the existence of a unilateral causal association from the credit volume growth rates toward economic growth and even concluded that growth accelerated financial development in a broader sense. In this study, it was seen that consumer and mortgage credits were included in the model as a sub-component of total credits.

Özcan and Arı (2011) examined the association between financial developments and economic growth in Turkey utilizing the data obtained for the 1998-2009 period. In the analyses performed through the VAR model, the impact of total credit volume extended to the private sector on economic growth was not detected. Instead, a causal association was identified from economic growth to developments in bank credit volume.

Karaca (2012), in the study conducted utilizing the quarterly data obtained for Turkey over the period from 1990:01 to 2011:04, determined a unilateral positive causal association from financial development toward economic growth. Therefore, it concluded that financial development accelerated economic growth by increasing access to credits and supporting investments.

Egbetunda (2012) analyzed the relations between commercial banks' credits and economic growth in Nigeria over the period between 1982 and 2009. Empirical findings revealed a longterm correlation between variables. Thus, the fact that both variables acting together in the long-run opened up an important field of application to monetary policies primarily for creating a positive cycle between variables. 
Oluitan (2012) explicated the influence of bank credits on economic growth in Nigeria between 1970-2006. The Johansen cointegration and Granger causality test results suggested that bank credits had a positive effect on the economic developments in Nigeria. Thus, it was emphasized that an effective credit market should be established prior to increasing economic activities in Nigeria.

Leitao (2012) analyzed the association between economic growth and bank credits for the EU27 between 1990 and 2012. In the dynamic panel data analysis utilizing the GMM estimators, it was detected that bank credits had an adverse impact on growth.

As a result of their analysis with a larger data set (65 countries), Narayan and Narayan (2013) concluded that bank credits generally had an adverse impact on economic growth, although there might have been geographically different outcomes.

Vurur and Özen (2013) examined the interaction between bank credits and economic growth based on obtained data from 1998 to 2012. Granger Causality Test results developed on the VAR model indicated that there was a causal association from economic growth toward credits.

Finally, a group of researchers detected the existence of a bilateral association between economic growth and bank credits in Turkey. Accordingly, developments in bank credits affected economic growth positively, whereas economic growth had an affirmative impact on bank credits.

Mercan (2013) analyzed the effect of changes in bank credit volume on economic growth in Turkey within the framework of the Bounds Test Approach. As a result of the analyses conducted utilizing quarterly data over the period between 1992 and 2011, a bilateral association was found between economic growth and bank credit volume. Accordingly, developments in bank credits affected economic growth, whereas developments in economic growth also affected bank credits positively.

Onuorah and Ozurumba (2013) analyzed the association between various bank credit types and economic development for the period between 1980-2011 in Nigeria. The results revealed that bank credits did not encourage economic growth, however, developments in the area of economic growth had an affirmative impact on bank credit volume.

Akçelik, Ermişoğlu, and Oduncu (2013) stated that bank credits had valuable information about the GDP growth and could be used by policymakers. In their study utilizing the data obtained throughout the period of 2007-2012, they concluded that the ratio of the change in commercial credits to GDP provided a meaningful contribution to GDP growth estimates in Turkey.

Bektaş and Tuna (2013) concluded that no causal association was detected between bank credit volume and economic growth in Turkey according to the quarterly data obtained over the period between 1998: I - 2012: IV. Moreover, they pointed out that different results might have occurred due to the fact that the structural breaks occurred during the data periods.

Timsina (2014) examined the economic impacts of bank credits on the Nepalese economy for the period between 1975 and 2013. In the performed analyses utilizing the Johansen cointegration test and Error Correction Model, it was observed that bank credits had an affirmative effect on private-sector production volume in the long-run. Thus, it was 
appropriate for policymakers in Nepal to prefer bank credit expansion practices to achieve long-term economic growth.

Tiryaki (2014) claimed that credit indicators had a causal association with the current account deficit rather than with GDP growth, whereas failed to detect any association between the growth rate of total credits and GDP growth. Nevertheless, while the rate of total credit growth had a limited impact on the current account deficit, banks' leverage ratio had interestingly a negative causality with the growth rate of GDP and a positive causality with the current account balance, and the rate of conversion of the deposit into credits had no causality with the growth of GDP, whereas it had negative effects on the current account deficit.

Göçer et al. (2015) analyzed the influence of bank credits on economic growth utilizing the quarterly data on bank credits obtained over the period between 2000-2012 in Turkey. As a result of the analysis performed via the cointegration test and dynamic least squares method, it was determined that employment and economic growth increased as bank credit volume was expanded. In contrast to the aforementioned outcomes, certain studies identified the presence of causality from economic growth toward bank credit volume expansion in Turkey.

Tahir et al. (2015) analyzed the effect of bank credits on economic growth between 1973 and 2013 for the Pakistani economy. As a result of cointegration and causality tests, bank credits were detected to have an adverse effect on economic growth in Pakistan.

Duican and Pop (2015) examined the effect of developments in credit volume on economic growth for the period 2005-2014 utilizing data obtained from 8 different regions in Romania. Panel regression analysis results revealed that the developments in credit activities had a crucial impact on the level of national income.

Mushtaq (2016) explicated the association between bank credits and economic growth for the Pakistani economy between 1961-2013. Johansen Cointegration and Granger Causality Test results asserted that economic development had a significant influence on the demand for bank credits.

Guerra (2017) analyzed the association between bank credits and economic growth in Mexico between 2001 and 2016 utilizing quarterly data. As a result of econometric analyses carried out within the framework of Granger Causality and VAR, a unilateral causality association was found from economic growth to bank credits. Accordingly, while the economic growth increased the will of the banks to extend credit by changing future expectations positively, firms and households demanded more credits for increasing production and consumption activities.

Several studies in the literature detected a bilateral association between bank credits and economic growth.

Fufa and Kim (2018) analyzed the influence of developments in bank credit and stock exchange on economic growth for 64 high- and middle-income country groups, utilizing the GMM estimator for the period between 1989 and 2012. The results revealed that the financial system affected economic growth in different ways in different income groups through developments in bank credit and stock exchange. Accordingly, it was determined that especially in middle-income country groups, developments in bank credits affected economic growth even more. 
There are studies indicating that bank credits have a positive impact on the economy, as well as research studies that identify the negative impacts in the literature. Here, especially the problems caused by bank credits caused by overheating in the economy are emphasized. Accordingly, the increasing inflation rates due to the development in bank credits might have caused many problems with the uncertainty in the economy.

Utilizing the quarterly data obtained between 2001 and 2015 in Latvia, Saksonova, and Koleda (2017) analyzed the impact of the commercial bank activities on the economy. The results of the Johansen Cointegration and Granger Causality Tests indicated the presence of mutual interaction between banking activities and economic growth.

\section{Data and Methodology}

\section{Data}

The analysis of this study, which examines the effects of the asset sizes of deposit banks operated in the public (PUBB) and private sector (PRIB) on the Gross Domestic Product (GDP) separately, is conducted utilizing a quarterly dataset. The beginning of the analysis period is determined as 2010: Q1 upon considering the possible impacts of the global economic crisis. The last period based on the most recent data release schedule is 2019: Q3. Accordingly, the analysis period of the study is determined as 2010: Q1 - 2019: Q3. The data of 3 publicly-owned (Türkiye Cumhuriyeti Ziraat Bankası A.Ş., Türkiye Vakıflar Bankası T.A.O., Türkiye Halk Bankası A.Ş.) and 25 privately-owned deposit banks (Akbank T.A.Ş., Anadolubank A.Ş., Fibabanka A.Ş., Turkish Bank A.Ş., Türk Ekonomi Bankası A.Ş., Türkiye İş Bankası A.Ş., Yapı Kredi Bankası A.Ş., Türkiye Garanti Bankası A.Ş., Finans Bank A.Ş., Denizbank A.Ş., ING Bank A.Ş., HSBC Bank A.Ş., Fortis Bank A.Ş., Şekerbank T.A.Ş., Arap Türk Bankası A.Ş., Citibank A.Ş., Deutsche Bank A.Ş., Alternatif Bank A.Ş., Adabank A.Ş., Millennium Bank A.Ş., Tekstil Bankası A.Ş., Bank Mellat, Société Générale (SA), JPMorgan Chase Bank N.A., The Royal Bank of Scotland N.V.) used in the analysis are obtained from different data sources.

The asset sizes of both privately- and publicly-owned deposit banks are obtained from the official website (www.tbb.org.tr) of Banks Association of Turkey. In compliance with the objective of the study, foreign capital banks established in Turkey, foreign banks with operating branches in Turkey, as well as investment and participation banks are not included in the sample of the study. The combined dataset related to the banks is the current amount of the total assets of banks in Turkish Lira (TL). The GDP data obtained from the Turkish Statistical Institute (TSI) in the same direction are also expressed in current prices. In terms of coordination depending on the content of the study, the seasonally adjusted GDP volume values at current prices are obtained quarterly and used in the analyses.

\section{Methodology}

In the econometric analysis, it is a prioritized process to examine whether or not the variables included in the study are stationary in terms of their level values. Upon arguing stationary and non-stationary time-series, the presence of unit roots should be tested to avoid the spurious regression problem (Harris, 1995). There are different methods to determine the stationarity of time-series. In this study, the Augmented Dickey-Fuller (ADF) and PhilipsPerron (1988) (PP) unit root tests are utilized. The PP unit root test suggests an asymptotic result for combined t-statistical regression and OLS estimators that allow for weakly 
dependent and heterogeneously distributed innovations. In practice, the ADF and PP tests are usually used to complement each other.

In a dynamic model, it is apparent that the value of any variable in the current period is affected by its values belonging to the previous period or periods. Therefore, the aforementioned variable may be affected by all kinds of information regarding the previous period, and accordingly the shocks to which it has been exposed. The long-run property of a series can be revealed by determining the extent to which the value of the variable in the previous period affected the current period. Therefore, it is sufficient to make a regression of the value of the series with the previous value in each period in order to comprehend how the series comes from a "data generation process". Upon defining the series in question as $Y_{t}$, the following equation is obtained:

$$
\mathrm{Y}_{\mathrm{t}}=\beta \mathrm{Y}_{\mathrm{t}-1}+\mathrm{u}_{\mathrm{t}} \quad \mathrm{u}_{\mathrm{t}} \approx \mathrm{N}\left(0, \sigma^{2}\right)
$$

If the value of $p$ is equal to 1 in Equation (1), the $Y_{t}$ variable is affected by its previous value, that is, the shocks to which it has been exposed. If the value of $p$ is less than 1 , even if the shocks in the past persist to affect for a certain period, this effect will gradually decrease and disappear completely after a short period. Hence the hypothesis is shown as follows:

$\mathrm{H}_{0}: \mathrm{p}=1$, the series contains unit roots (Non-stationary series).

$\mathrm{H}_{\mathrm{a}}: \mathrm{p}<1$, the series does not contain any unit-roots (Stationary series).

The above hypothesis was developed by Dickey-Fuller. Dickey-Fuller test is one of the simplest tests in terms of its simplicity and usability. The DF- $\tau$ distribution calculated under the absence hypothesis was calculated using the Monte Carlo technique. According to this technique, $\mathrm{Y}_{\mathrm{t}}=\beta \mathrm{Y}_{\mathrm{t}-1}+\mathrm{u}_{\mathrm{t}}$ model under the null hypothesis $(\mathrm{p}=1)$ is the process that generates data. Random samples were created from the normal distribution curve for ut in the model. All of these examples are a large number of $Y_{t}$ samples consistent with the process that generates the data. Then, for each $Y_{t}$, using the model (1-L) $Y_{t}=\Delta Y_{t}=(\beta-1) Y_{t-1}+u_{t}, \beta$ was estimated freely to change and percentages were calculated so as to reject the null hypothesis regarding the parameters. These values are DF- $\tau$ critical values corresponding to significance levels at various percentages rejecting the null hypothesis. Critical values of DF- $\tau$ are more negative than standard $t$. If $Y_{0}$, which is the initial value of $Y_{t}$, is unknown in the data generating process, the constant must be added upon performing the unit-root test. In this case, the model is formulated as follows:

(1-L) $\mathrm{Y}_{\mathrm{t}}=\Delta \mathrm{Y}_{\mathrm{t}}=\mu+(\beta-1) \mathrm{Y}_{\mathrm{t}-1}+\mathrm{u}_{\mathrm{t}}$

DF critical values for this model are shown as $\left(\tau_{\mu}\right)$. If it is stated that the data generating process is a stationary process around a deterministic trend, the model is formulated as follows:

$(1-\mathrm{L}) \mathrm{Y}_{\mathrm{t}}=\Delta \mathrm{Y}_{\mathrm{t}}=\mu+\delta_{\mathrm{t}}+(\beta-1) \mathrm{Y}_{\mathrm{t}-1}+\mathrm{u}_{\mathrm{t}}$

The statistic used for the unit-root test in this model is the $\left(\tau_{t}\right)$ statistic (Harris, 1995). In the model in Equation (2), $\delta$ and $\beta$ can be tested concurrently. In Dickey-Fuller (1981), there is a non-standard F distribution created for this test. Accordingly, using the model in Equation (2), if $\mathrm{H}_{0}:(\beta=1)$ is not rejected with $\mathrm{DF}$, and $\mathrm{H}_{0}:((\beta-1)=\delta=0)$ is rejected with $\mathrm{F}$, this indicates a significant trend under the unit-root null hypothesis. In this case, the $t$ distribution is asymptotically normal, that is, the standard $t$ can be used instead of DF for critical values when $\mathrm{n} \rightarrow \infty$ (Çabuk, 1995). If the residuals $\left(\mathrm{u}_{\mathrm{t}}\right.$ ) obtained by estimating the equations indicate 
autocorrelation, the unit-root test results are not valid. Dickey and Fuller developed the "Augmented" DF test to overcome such a problem. The model developed for the ADF test is as follows:

$\Delta Y t=\mu+\delta_{t}+(\beta-1) Y_{t-1} \sum_{i=1}^{k} \lambda i \quad \Delta Y_{t-i}+u_{t}$

In the analysis, the non-stationarity of series (containing unit root) requires the analysis methodology to be examined for long-term associations. In case of the same degree of cointegration between the variables, it should be examined whether or not the variables act concurrently in the long-run. In this study, the cointegration analysis developed by Johansen (1988) is performed. In the cointegration test of Johansen (1988), based on the vector autoregressive model in which all variables are assumed as endogeneous, the maximum likelihood method is used to estimate the vectors and the rank related to the coefficient matrix. When all series are integrated at the same level, Johansen (1988) tests whether or not a longterm relationship exists between the series with the "full information maximum likelihood method". The existence of cointegration between series can be measured by performing the cointegration test developed by Johansen (1988). Johansen test is based on VAR analysis (Tar1 $\&$ Yildirım, 2009). The system of equations in the model is as follows:

$Y_{t}=\sum_{i=1}^{p} A_{i} Y_{t-1}+\beta X_{t}+u_{t}$

Cointegration, in simple terms, defines the long-run association among non-stationary series. Estimating the long-term coefficients under the presence of the unit root by the Ordinary Least Squares (OLS) method may be erroneous due to autocorrelation and endogeneity problems. In order to overcome these problems that may be caused by the OLS method performed under the presence of the unit root; the FMOLS developed with Phillips and Hansen (1990), the DOLS developed by Saikkonen (1992) and Stock and Watson (1993, and the Canonical Cointegrating Regression (CCR) developed by Park (1992) can be used. Although all three methods have the success of giving reliable results in small samples, they try to mitigate the endogeneity problem with different methods. For example, the FMOLS tries to eliminate the endogeneity problem with kernel estimators. The DOLS, on the other hand, tries to overcome the problem arising from the small sample and dynamic structure by including the lagged value of the explanatory variables and the next value in the cointegration regression. The CCR tries to overcome this problem by eliminating the second-order deviation of the estimators in the cointegration regression. These methods have no superiority over each other. However, obtaining results with all three methods is an advantage in eliminating the endogeneity problem of cointegration regression with different assumptions. In this study, firstly, the unit root test is performed with the ADF and PP tests, then the appropriate lag length is determined, Johansen cointegration analysis is conducted, and finally, cointegration estimators are tried to be determined by the FMOLS, DOLS, and CCR methods. The aim of the study is to explicate the nexus between economic growth and the asset sizes of both publiclyand privately-owned banks established in Turkey. Accordingly, the nexus is analyzed using the quarterly data obtained throughout the period between 2010:01 - 2019:03. Econometric models are determined as follows:

$\begin{array}{ll}L G D P=c+L P U B B_{t}+e_{t} & \text { for Publicy-Owned Banks } \\ L G D P=c+L P R I B_{t}+e_{t} & \text { for Privately-Owned Banks }\end{array}$ 


\section{Findings}

Banks' assets consist of financial assets, financial assets measured at amortized cost, assets held for sale and discontinued operations, partnership investments, tangible assets, intangible assets, investment properties, deferred tax assets, current tax assets. From this aspect, an increase in asset size is considered as financial development. Generally, the question of how financial development affects economic growth is responded to by certain transmission mechanisms that can be explained by various theories. Among these, there are savings and investments related to banks. In many studies where bank deposits and credit data are discussed, financial development is expressed in a very limited portion of bank assets. In this study, unlike other similar studies, the extent to which the development of the direct banking system influences economic growth is investigated.

Accordingly, since the most inclusive variable to be selected is asset size, the analyses are conducted based on the effects of asset size of different bank groups on economic growth. In this regard, upon examining the assets of privately- and publicly-owned deposit banks in Figure 1, it is seen that total assets of publicly-owned deposit banks exceed the assets of privately-owned deposit banks since 2018. Accordingly, it can be said that publicly-owned banks perform asset management more effectively than privately-owned banks. It is also understood from Figure 1 that the rate of asset growth of privately-owned deposit banks decreased over time.

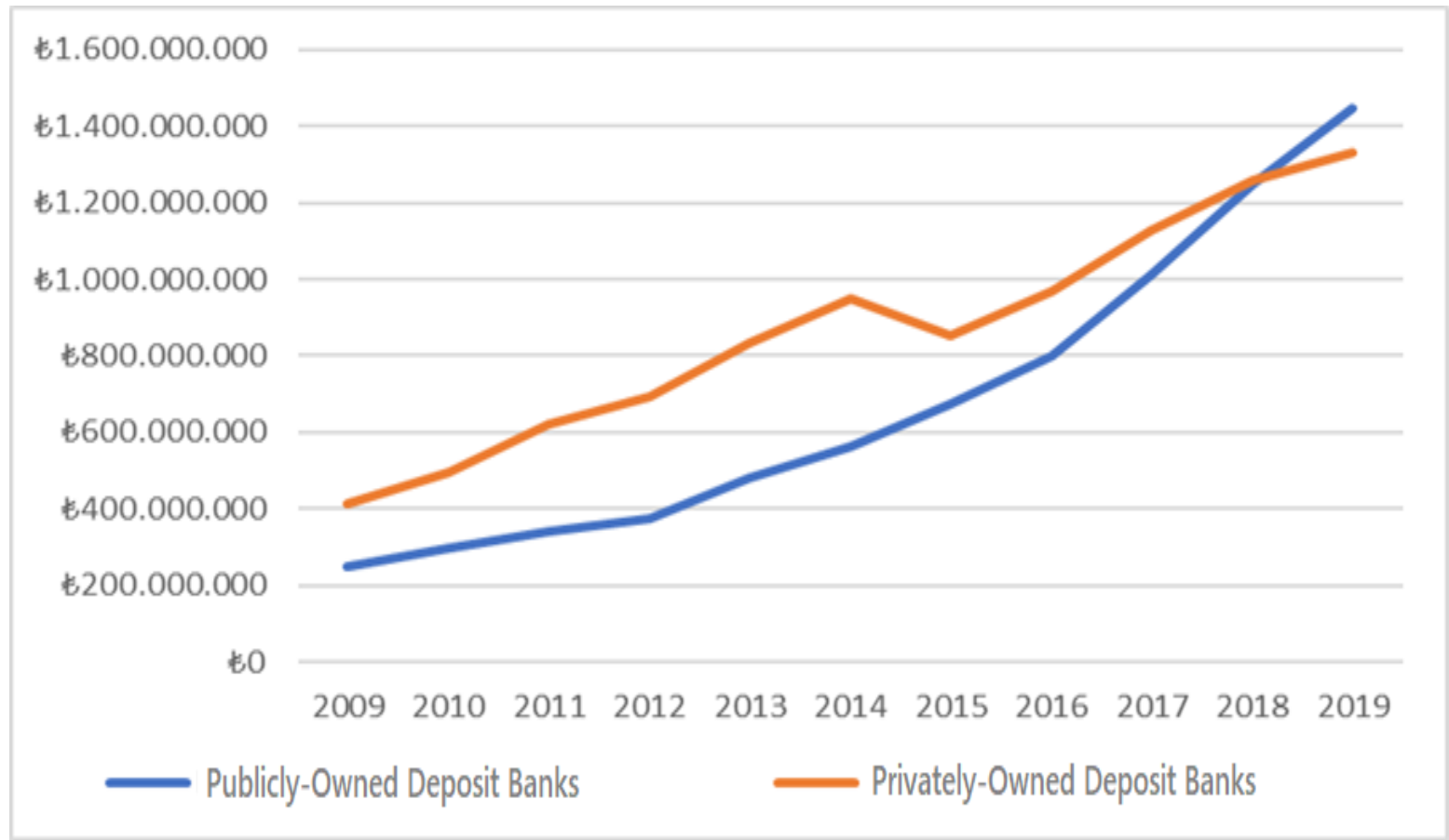

Figure 1. Development of privately- and publicly-owned deposit banks' assets

The development of seasonally adjusted GDP data is illustrated in Figure 2. Upon examining the figure, an increase is observed over the years. 
The Impacts of Publicly and Privately-Owned Banks on Economic Growth in Turkey: A Comparative Analysis

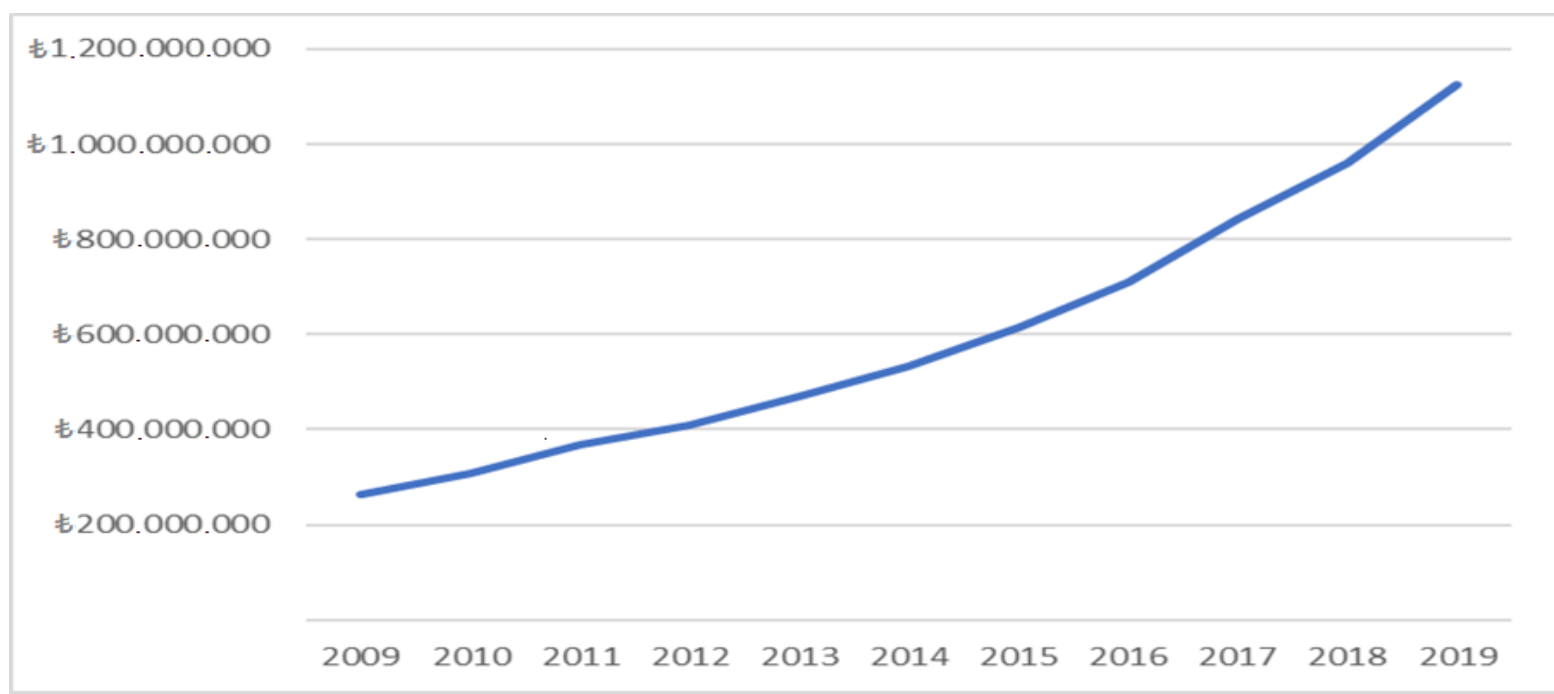

Figure 2. Development of the GDP

Upon evaluating Figure 1 and Figure 2 together, it is remarkable that there is a dynamic increase in all series. The descriptive statistics of logarithmic seasonally adjusted GDP volume values and the asset sizes of publicly- and privately-owned banks are included in Table 1 as LGDP, LPUBB, and LPRIB, respectively. Upon analyzing Table 1, it is noticed that the assets of publicly-owned banks have the highest standard deviation. Besides, the standard deviation of the assets of private banks is the lowest compared to other data.

Table 1. Descriptive Statistics

\begin{tabular}{lccc}
\hline & LGDP & LPUBB & LPRIB \\
\hline Mean & 8,7349 & 8,7642 & 8,9248 \\
Maximum & 9,0354 & 9,1609 & 9,1507 \\
Minimum & 8,4310 & 8,4131 & 8,6278 \\
Std. Dev. & 0,1746 & 0,2272 & 0,1428 \\
\# of Observations & & 39 & \\
\hline
\end{tabular}

The results of ADF and PP unit root tests performed can be seen in Table 2. In Table 2, it can be seen that LGDP, LPUBB, and LPRIB series contain unit root at the level, but are stationary at the difference level. Accordingly, it can be said that all series are I(1).

Table 2. Unit Root Test Results

\begin{tabular}{|c|c|c|c|c|c|}
\hline \multirow[b]{2}{*}{ Level/Diff. } & \multirow[b]{2}{*}{ Variables } & \multicolumn{2}{|c|}{ ADF } & \multicolumn{2}{|r|}{ PP } \\
\hline & & Constant & $\begin{array}{c}\text { Constant and } \\
\text { Trend }\end{array}$ & Constant & Constant and Trend \\
\hline \multirow{2}{*}{ Level } & \multirow{2}{*}{ LGDP } & -0.0036 & -1.7146 & -0.2693 & -2.9304 \\
\hline & & $(0.952)^{*}$ & $(0.724)$ & $(0.920)$ & $(0.164)$ \\
\hline
\end{tabular}




\begin{tabular}{cccccc}
\hline \multirow{2}{*}{ LPUBB } & 0.7185 & -1.9442 & 0.7895 & -1.9214 \\
& $(0.991)$ & $(0.612)$ & $(0.992)$ & $(0.623)$ \\
\cline { 2 - 6 } & \multirow{2}{*}{ LPRIB } & -1.6807 & -2.4858 & -1.7582 & -2.4858 \\
& $(0.432)$ & $(0.332)$ & $(0.394)$ & $(0.332)$ \\
\hline \multirow{2}{*}{ Difference } & \multirow{2}{*}{$\Delta$ LGDP } & -9.7394 & 9.6001 & -9.8194 & -9.6831 \\
\cline { 2 - 6 } & \multirow{2}{*}{$\Delta$ LPUBB } & $(0.000)$ & $(0.000)$ & $(0.000)$ & $(0.000)$ \\
\cline { 2 - 6 } & & -6.4104 & -6.5250 & -6.4093 & -6.5238 \\
& \multirow{2}{*}{$\Delta$ LPRIB } & $(0.000)$ & $(0.000)$ & $(0.000)$ & $(0.000)$ \\
\hline & -6.6640 & -6.7445 & -6.6632 & -6.7544 \\
\hline
\end{tabular}

* Probability values are indicated in parentheses.

Upon examining the probability values of the difference series, they are determined to be significant at a 99\% confidence interval. Findings obtained from Table 2 reveal that the existence of a potential cointegration between the series should be investigated. In this respect, the lag length is investigated separately with the AIC, SIC, and HQ information criteria to determine a possible cointegration between GDP and both publicly- and privately-owned bank groups separately. The results for the lag length can be observed in Table 3.

Table 3. Determining the Lag Length

\begin{tabular}{ccccccc}
\hline \multirow{2}{*}{ Lags } & \multicolumn{3}{c}{ LGDP - LPUBB } & \multicolumn{3}{c}{ LGDP - LPRIB } \\
\cline { 2 - 6 } & AIC & SIC & HQ & AIC & SIC & HQ \\
\hline 0 & -6.2710 & -6.1821 & -6.2403 & -4.6857 & -4.5969 & -4.6551 \\
\hline 1 & -12.154 & $-11.887^{*}$ & $-12.062^{*}$ & -10.463 & $-10.197^{*}$ & -10.371 \\
\hline 2 & $-12.205^{*}$ & -11.761 & -12.052 & -10.557 & -10.113 & $-10.404^{*}$ \\
\hline 3 & -12.012 & -11.390 & -11.797 & -10.375 & -9.7532 & -10.160 \\
\hline 4 & -11.788 & -10.988 & -11.512 & $-10.676^{*}$ & -9.8762 & -10.400 \\
\hline
\end{tabular}

In terms of coordination between the lag lengths determined in Table 3, the suitable lag length is determined to be 1 according to the SIC information criteria for both distinct bank groups. Apart from being the most commonly used lag length criterion, the SIC information criterion is chosen since other lag length criteria are also compatible with the SIC. According to this, the results of Johansen's cointegration analysis are presented in Table 4.

Table 4. Johansen Cointegration Test Results

\begin{tabular}{lccccc}
\hline Model & Hypothesis & Eigen-value & Trace Statistic & $\mathbf{5 \%}$ Critical Value & Probability \\
\hline LGDP - LPUBB & $\mathrm{r}=0$ & 0.6067 & 42.570 & 20.261 & 0.000 \\
\hline
\end{tabular}


The Impacts of Publicly and Privately-Owned Banks on Economic Growth in Turkey: A Comparative Analysis

\begin{tabular}{lccccc}
\hline & $r \leq 1$ & 0.1952 & 8.036 & 9.164 & 0.081 \\
\hline \multirow{2}{*}{ LGDP - LPRIB } & $r=0$ & 0.6741 & 47.381 & 20.261 & 0.000 \\
\cline { 2 - 6 } & & 0.1472 & 5.892 & 9.164 & 0.081 \\
\hline
\end{tabular}

The results presented in Table 4 reveal the existence of cointegration between LGDP - LPUBB as well as between LGDP - LPRIB. Upon determining the cointegration between the series, a $95 \%$ significance level is considered. The null hypothesis of $r$ (cointegration rank) $=0$ implies the nonexistence of any cointegration, whereas $r \leq 1$ means cointegration rank is less than or equal to 1 . It is asserted that both publicly- and privately-owned deposit banks are associated with the GDP in the long-run. Results regarding the FMOLS, DOLS, and CCR cointegration regressions, which indicate the direction of the association within both bank groups, are shown in Table 5.

Table 5 Cointegration Regression Results

\begin{tabular}{l|c|c|c}
\hline \multicolumn{4}{c}{ Panel 1: LGDP = C + LPUBB } \\
\hline \multirow{2}{*}{ C } & FMOLS & DOLS & CCR \\
& 2.0379 & 2.0255 & 2.0779 \\
LPUBB & $(0.000)^{*}$ & $(0.000)$ & $(0.000)$ \\
& 0.7637 & 0.7655 & 0.7595 \\
\hline \multirow{2}{*}{ C } & $(0.000)$ & $(0.000)$ & $(0.000)$ \\
\hline \multirow{2}{*}{ LPRIB } & \multicolumn{2}{|c|}{ Panel 2: LGDP = C + LPRIB } & 6.5858 \\
& 6.610 & 6.662 & $(0.000)$ \\
\hline
\end{tabular}

"Probability values are indicated in parentheses.

Results shown in Table 5 assert that there is no meaningful difference among the FMOLS, DOLS, and CCR methods performed with different assumptions and analytical methods. Coefficients and probability values on the table are clearly presented. Accordingly, it can be seen that both publicly- and privately-owned deposit banks have positive impacts on the GDP in the long-run. Upon comparing the results of both bank groups, it is seen that the long-term affirmative effect of publicly-owned banks on the GDP is higher than that of privately-owned deposit banks.

\section{Conclusions}

Economic growth as well as the factors that trigger economic growth are among the most prominent research topics in the field of economic policy and theory. In this study, investigating whether or not the banking system influences economic growth, the effect of the development of the banking system on economic growth is tried to be detected through a series of tests. Unlike other similar studies, the development of the banking system is 
considered as the growth in banks' total assets. In this way, it is tried to take the direct influence of the financial demand on providing funds to the real economy into consideration, as well as indirect impacts that cannot be foreseen financially. The analysis period is determined as the most inclusive interval between 2010: Q1 - 2019: Q3 and the impacts of publicly- and privatelyowned deposit banks on the GDP are examined separately. Findings obtained from the analyses, in which cointegration testing, the FMOLS, DOLS, and CCR cointegration regressions are conducted, reveal that both publicly- and privately-owned deposit banks positively affect the GDP. These obtained results can be used by policymakers as suggested by Akçelik et al. (2013). Accordingly, if the development of the banking system has long-term positive impacts on the economy, it may be recommended that the economic authorities who wish to benefit from the positive externality created by the banking system implement special regulations regarding the banks. On the other hand, asset growths of both bank groups included in the sample positively affect the GDP; nonetheless, it is found that publicly-owned deposit banks affect GDP more compared to privately-owned deposit banks. Turgut (2019), which considered a similar bank group distinction, reported completely different results. Turgut (2019) asserted that the rise in the total credit volume of publicly-owned banks decreased economic growth, whereas the rise in the total credit volume of privately-owned banks increased the GDP. It is thought that the variable used in the analysis accounts for such a difference between these two studies in terms of publicly-owned banks. In this study, both direct and indirect impacts of the asset size on the GDP are taken into account, however, only the credits were considered and a limited result was achieved in Turgut (2019). Moreover, the reason for such difference is foreseen in Bektaş and Tuna (2013). In the related study, when there was no relationship between credits and economic growth, it was stated that this was due to the structural breaks experienced on economic data from time to time. Upon considering the results from this point of view, the analysis period was evaluated in Turgut (2019) and it was determined that the analyses were performed throughout a different period such as 2003:Q1 - 2017:Q3. Subsequently, the result of the fact that publicly-owned deposit banks have more affirmative impacts on the GDP compared to privately-owned deposit banks reveals that public banks serve more for national economic purposes. In this regard, the findings obtained by examining the development of asset sizes over the years reveal that the total assets of privately-owned deposit banks were above of publicly-owned deposit banks until 2018, but this situation changed after 2018. Nevertheless, the higher impact of publiclyowned banks with their smaller asset sizes reveals that indirect mechanisms of the impact of publicly-owned banks are also effective on economic growth. Upon considering this situation, it may be recommended to take policy measures to increase the economic contribution of privately-owned banks.

Upon examining the comprehensive literature on economic growth and financial development, it is noticed that there is no consensus regarding the direction of the association. For example, Beck and Levine (2004), Chakraborty (2008), Oluitan (2012), and Timsina (2014) found a positive causality running from financial development toward economic growth. Leitao (2012), Narayan and Narayan (2013), and Tahir et al. (2015), however, detected an adverse effect regarding the same issue. As the reason underlying this difference, Fufa and Kim (2018) stated that the potential impact between economic growth and financial development would differ according to the income group of countries. Furthermore, although the literature is meticulously reviewed, it can be said that the influence on economic growth is analyzed by utilizing the data of both credits extended by banks and/or deposit amounts 
collected by banks. However, this form of examination reflects a limited perspective. A study in which the asset size is considered regarding both direct and indirect effects of banks on economic growth cannot be observed within the knowledge of the researcher. Therefore, comparing the outcomes obtained in this study with of other studies in the literature may cause a great deal of controversy. For instance, Özcan and Arı (2011) could not detect any significant impact of total credit volume on the GDP in Turkey. On the contrary, Güven (2002), Aslan and Küçükaksoy (2006), Mercan (2013), Vurur and Özen (2013), and Göçer et al. (2015) found positive impacts of credits on economic growth.

The diversity of the results in the related literature comprised of the empirical studies conducted on the subject arises from such factors as distinct analysis periods, the direction of financial developments throughout the relevant period, and the data used to represent the banking system. Undoubtedly, the positive association determined in this study should be taken into account within the limitations of the analysis period and the data of total assets. Of course, in this study, the impacts of different bank groups on economic growth, especially along with the asset size mechanism, are presented in a series of disputable findings. However, despite all the scientific benefits provided, some deficiencies of the study can be mentioned. For example, investment banks, as well as foreign capital banks established in Turkey, are not included in the analyses. Also, the study is conducted only in the national sense, disregarding the banking sectors in other countries.

\section{References}

Akçelik, Y., Ermişoğlu, E.. \& Oduncu, A. (2013). GDP growth and credit data. Central Bank of the Republic of Turkey, Working Paper, No: 13/27, July.

Aklan, N., \& Nargeleçekenler, M. (2008). Para politikalarının banka kredi kanalı üzerindeki etkileri. İstanbul Üniversitesi Siyasal Bilgiler Fakültesi Dergisi, (39), 109-132.

Aslan, A.G.Ö., \& Küçükaksoy, İ. (2006). Finansal gelişme ve ekonomik büyüme ilişkisi: Türkiye ekonomisi üzerine ekonometrik bir uygulama. Ekonometri ve İstatistik e-Dergisi, (4), 25-38.

Aslan, Ö., \& Korap, H. L. (2006). Türkiye'de finansal gelişme ekonomik büyüme ilişkisi. Muğla Üniversitesi Sosyal Bilimler Enstitüsü Dergisi, (17), 1-20.

Beck, T ., \& Levine, R. (2004). Stock markets, banks, and growth: Panel evidence. Journal of Banking E Finance, 28(3), 423-442. DOI: https://doi.org/10.1016/S0378-4266(02)00408-9

Bektaş, H., \& Tuna, K. (2013). Kredi hacminin ekonomik büyüme üzerindeki rolünün incelenmesi: Türkiye örneği. Marmara Üniversitesi, Finansal Araştırmalar ve Çalışmalar Dergisi, 9, 139-150.

Calderón, C., \& Liu, L. (2003). The direction of causality between financial development and economic growth. Journal of Development Economics, 72(1), 321-334. DOI: https://doi.org/10.1016/S0304-3878(03)00079-8

Ceylan, S., \& Durkaya, M. (2010). Türkiye'de kredi kullanımı ekonomik büyüme ilişkisi. Atatürk Üniversitesi I.I.I.B.F Dergisi, 24 (2), 21-33.

Chakraborty, I. (2008). Does financial development cause economic growth? The case of India. South Asia Economic Journal, 9 (1). DOI: https://doi.org/10.1177/139156140700900105

Çabuk, A. (1995). Makroekonomik değişkenlerde birim kök, Çukurova Üniversitesi, Araştırma Fonu Projesi / Proje No: İ̈BF 95/4. 
Dickey, D.A., \& Fuller, W.A. (1979). Distribution of the estimators for autoregressive time-series with a unit root. Journal of the American Statistical Association,74 (366), 427-431. DOI: https://doi.org/10.1080/01621459.1979.10482531

Dickey, D.A., \& Fuller, W.A. (1981). Likelihood ratio statistics for autoregressive time-series with a unit root. Econometrica, 49 (4), 1057-1072. DOI: 10.2307/1912517

Dişbudak, C. (2010). Analysing the bank credit-economic growth nexus in Turkey. European Journal of Economics, Finance and Administrative Sciences, 23, 34-48.

Duican, E.R., \& Pop, A. (2015). The implications of credit activity on economic growth in Romania. Procedia Economics and Finance, 30, 195-201. DOI: https://doi.org/10.1016/S2212-5671(15)01286-1.

Egbetunde, T. (2012). Bank credits and rural development in Nigeria (1982-2009). International Journal of Finance and Accounting, 1 (3), 45-52. DOI:10.5923/j.ijfa.20120103.04

Fufa, T ., \& Kim, J. (2018). Stock markets, banks, and economic growth: Evidence from more homogeneous panels. Research in International Business and Finance, 44, 504-517. DOI: 10.1016/j.ribaf.2017.07.120

Göçer, İ., Mercan, M., \& Bölükbaş, M. (2015). Bankacılık sektörü kredilerinin istihdam ve ekonomik büyüme üzerindeki etkileri: Türkiye ekonomisi için çoklu yapısal kırılmalı eş bütünleşme analizi. Hacettepe Üniversitesi, İ.̇.B.F Dergisi, 33 (2), 65-84. DOI: https://doi.org/10.17065/huiibf.58825

Guerra, E.A.R. (2017). The economic growth and the banking credit in Mexico: Granger causality and short-term effects, 2001Q1-2016Q4. Economia Informa, 406, 46-58. DOI: https://doi.org/10.1016/j.ecin.2017.10.004

Harris, R.I.D. (1995). Using cointegration analysis in econometric modelling. Harlow London: Prentice Hall.

Johansen, S. (1988) Statistical analysis of cointegration vectors. Journal of Economics Dynamic and Control, 12(2-3), 231-254. DOI: https://doi.org/10.1016/0165-1889(88)90041-3

Johansen, S., \& Juselius, K. (1990). Maximum likelihood estimation and inference on cointegration with application to the demand for money. Oxford Bulletin of Economics and Statistics, 52(2), 169210. DOI: https://doi.org/10.1111/j.1468-0084.1990.mp52002003.x

Karaca, O. (2012). Finansal gelişme ve ekonomik büyüme: Türkiye için bir nedensellik analizi. BDDK Bankacıllk ve Finansal Piyasalar Dergisi, 6 (2), 85-111.

Leitao, N.C. (2012). Bank credit and economic growth. Munich: MPRA No:42664.

Mercan, M. (2013). Kredi hacmindeki değişimlerin ekonomik büyümeye etkisi: Türkiye ekonomisi için sınır testi yaklaşımı. TBB Bankacılar Dergisi, 84, 54-71.

Mushtaq, S. (2016). Causality between bank's major activities and economic growth: Evidence from Pakistan. Financial Innovation, 2 (7), 1-11. DOI: 10.1186/s40854-016-0024-y

Narayan, P.K., \& Narayan, S. (2013). The short-run relationship between the financial system and economic growth: new evidence from regional panels. International Review of Financial Analysis, 29, 70-78. DOI: https://doi.org/10.1016/j.irfa.2013.03.012

Oluitan, R.O. (2012). Bank credit and economic growth: Evidence from Nigeria. International Business and Management, 5 (2), 102-110. DOI:10.3968/j.ibm.1923842820120502.1040

Onuorah, A.C., \& Anayochukwu, O.B. (2013). Bank credits: An aid to economic growth in Nigeria. Information and Knowledge Management, 3(3),41-50.

Özcan, F. (2007), Finansal Kalkınma ve İktisadi Büyüme Arasındaki İlişki: Dünya Ülkeleri ve Türkiye Örneği, Uzmanlık Yeterlilik Tezi, TCMB Bankacılık ve Finansal Kuruluşlar Genel Müdürlüğü, Ankara. 
Özcan B., \& Arı, A. (2011). Finansal gelişme ve ekonomik büyüme arasındaki ilişkinin ampirik bir analiz: Türkiye örneği. Business and Economics Research Journal, 2 (1), 121- 142.

Öztürkler H., \& Çermikli, A.H. (2007). Türkiye'de bir parasal aktarım kanalı olarak banka kredileri. Finans Politik ve Ekonomik Yorumlar, 44 (514), 57-68.

Park, J.Y. (1992). Canonical cointegrating regressions. Econometrica: Journal of the Econometric Society, 60(1), 119-143. DOI: 10.2307/2951679.

Phillips, P.C.B., \& Hansen, B.E. (1990). Statistical inference in instrumental variables regression with I(1) processes. The Review of Economic Studies 57, 99-125. DOI: https://doi.org/10.2307/2297545

Phillips, P.C.B., \& Perron, P. (1988). Testing for a unit root in time series regression. Biometrika 75 (2), 335-346. DOI: https://doi.org/10.1093/biomet/75.2.335

Saikkonen, P. (1992). Estimation and testing of cointegrated systems by an autoregressive approximation. Econometric Theory 8(1), 1-27. DOI: https://doi.org/10.1017/ S0266466600010720

Saksonova, S., \& Koḷeda, O. (2017). Evaluating the interrelationship between actions of Latvian commercial banks and Latvian economic growth. Procedia Engineering, 178, 123-130. DOI: https://doi.org/10.1016/j.proeng.2017.01.075

Sevim, C. (2016). Uluslararası para ve sermaye piyasaları. Ekonomi Işsletme Siyaset ve Uluslararası İlişkiler Dergisi, 2(2), 191-210.

Stock, J.H., \& Watson, M.W. (1993). A simple estimator of cointegrating vectors in higher order integrated systems. Econometrica: Journal of the Econometric Society, 61(4), 783-820. DOI: $10.2307 / 2951763$

Tahir, H.S., Shehzadi, I., Ishfaq, A., \& Ullah, M.R. (2015). Impact of bank lending on economics growth in Pakistan: an empirical study of lending to private sector. American Journal of Industrial and Business Management, 5, 565-576. DOI: 10.4236/ajibm.2015.58056

Tarı, R. \& Yıldırım, D. Ç. (2009). Döviz kuru belirsizliğinin ihracata etkisi: Türkiye için bir uygulama. Yönetim ve ekonomi: Celal Bayar Üniversitesi İiBF Dergisi, 16(2), 95-105.

Timsina, N. (2014). Impact of bank credit on economic growth in Nepal. NRB Working Paper, No:22.

Tiryaki, G. (2014). Banking leverage, credit indicators, current account balance and economic growth with their implications in Turkey (1999-2013). Marmara Üniversitesi, Finansal Araştırmalar ve Çalışmalar Dergisi, 11.

Topak, M.S., \& Talu. N.H.(2016). Internal determinants of bank profitability: Evidence from the Turkish banking sector. International Journal of Economic Perspectives, 10 (1), 37-49.

Turgut, K. (2019). Banka kredi hacmi ile iktisadi büyüme arasmdaki ilişki: Türkiye örneği. The relation between bank credits and economic growth: Turkish example (Master's Thesis, Hacettepe Üniversitesi Sosyal Bilimler Enstitüsü, Ankara). http://tez2.yok.gov.tr/

Vurur, N.S., \& Özen, E. (2013). Türkiye'de mevduat banka kredisi ve ekonomik büyüme ilişkisinin incelenmesi. Uşak Üniversitesi, Sosyal Bilimler Dergisi, 6 (3), 117-131. 